\title{
ANALISIS PENGARUH PARIWISATA TERHADAP PRODUK DOMESTIK REGIONAL BRUTO KABUPATEN / KOTA PROVINSI JAWA TIMUR 2011-2014
}

\author{
Yhoga Bagus Adhikrisna \\ PT. Bank Mandiri Tbk. \\ Wahyu Hidayat \\ Zainal Arifin \\ Fakultas Ekonomi dan Bisnis - Universitas Muhammadiyah Malang \\ Email: yhogabagusadhikrisna@yahoo.com
}

\begin{abstract}
This research is a quantitative research using panel data, the data used in the form of time series (2011-2014) and (29 districts and 9 cities in East Java) cross section. The data used in this study are secondary data obtained from the Central Statistics Agency (BPS) and the Department of Culture and Tourism of the Province of East Java. The analytical method used is linear regression analysis with panel data models fixed effects Eviews 9 software tools are used. The results showed that the growth product regencies / regional gross domestic cities in East Java province from the year 2011-2014 increases by an average of 11,29 percent. $F$ test results showed a variable number of tourists, the number of hotels and the number of simultaneous influential restaurants of the regional gross domestic product. T test results showed a variable number of tourists, the number of hotels and the number of restaurants individually significant effect with the positive direction of regional gross domestic product in the District / City in the province of East Java. Models using the fixed effects model produces R2 value of $98 \%$.
\end{abstract}

Keywords: tourist, hotel, restaurant, gross domestic product

\begin{abstract}
ABSTRAK
Penelitian ini merupakan penelitian kuantitatif dengan menggunakan data panel, data yang digunakan berupa time series (tahun 2011-2014) dan cross section (29 Kabupaten dan 9 Kota di Provinsi Jawa Timur). Jenis data yang digunakan dalam penelitian ini adalah data sekunder yang diperoleh dari Badan Pusat Statistik (BPS) dan Dinas Kebudayaan dan Pariwisata Provinsi Jawa Timur. Metode analisis yang digunakan adalah metode analisis regresi linier data panel dengan model Fixed Effect digunakan alat bantu software Eviews 9. Hasil penelitian menunjukkan bahwa perkembangan produk domestik regional bruto Kabupaten/Kota di Provinsi Jawa Timur dari tahun 2011-2014 mengalami peningkatan dengan rata-rata sebesar 11,29 persen. Hasil uji $F$ menunjukan variabel jumlah wisatawan, jumlah hotel dan jumlah restoran berpengaruh secara serentak terhadap produk domestik regional bruto. Hasil uji t menunjukan variabel jumlah wisatawan, jumlah hotel dan jumlah restoran secara individu berpengaruh signifikan dengan arah positif terhadap produk domestik regional bruto di Kabupaten / Kota di Provinsi Jawa Timur. Permodelan menggunakan Fixed Effect Model menghasilkan nilai $R^{2}$ sebesar $98 \%$.
\end{abstract}

Kata kunci :Wisatawan, Hotel, Restoran, Produk Domestik Regional Bruto 


\section{PENDAHULUAN}

Undang-Undang Nomor10 tahun 2009 Tentang Kepariwisataan yang menyatakan bahwa Penyelenggaraan Kepariwisataan ditujukan untuk meningkatkan pendapatan nasional dalam rangka meningkatkan kesejahteraan dan kemakmuran rakyat, memperluas dan memeratakan kesempatan berusaha dan lapangan kerja, mendorong pembangunan daerah, memperkenalkan dan mendayagunakan obyek dan daya tarik wisata di Indonesia serta memupuk rasa cinta tanah air dan mempererat persahabatan antar bangsa.

Pariwisata memberikan kontribusi sebagai sumber pendapatan devisa, penciptaan lapangan kerja, kegiatan produksi dan pendapatan nasional (PDB), pertumbuhan sektor swasta dan pembangunan infrastruktur. Pariwisata juga berpotensi untuk mendorong penerimaan negara dari pajak, terutama pajak tidak langsung (Nizar, 2011).

Pengaruh pariwisata dalam Produk Domestik Bruto (PDB) terlihat dari kontribusi jasa pariwisata, penerimaan dan sektor pendukungnya. Sektor pariwisata merupakan sektor yang berbasis jasa dan sebagai salah satu sektor unggulan yang strategis dalam pembangunan nasional, karena mampu mendatangkan devisa bagi negara nomor dua setelah minyak dan gas (Heriawan, 2004).

Tabel 1. Perkembangan PDRBADHB Sektor Pariwisata dan Kontribusinya di Provinsi Jawa Timur Tahun 2011-2014

Perkembangan PDRB-ADHB Sektor Pariwisata (triliun Rp) dan Kontribusinya (persentase)

\begin{tabular}{lllll} 
& 2011 & 2012 & 2013 & 2014 \\
\hline $\begin{array}{l}\text { Jawa } \\
\text { Timur }\end{array}$ & 66,52 & 75,61 & 88,16 & 101,9 \\
\hline $\begin{array}{l}\text { Kontri- } \\
\text { Busi }\end{array}$ & 16,66 & 13,67 & 16,60 & 15,67 \\
& $\%$ & $\%$ & $\%$ \\
\hline
\end{tabular}

Sumber: Budpar Jatim Dalam Angka, 2014.

Berdasarkan data dari Dinas Kebudayaan dan Pariwisata Provinsi Jawa Timur pada tahun 2011 PDRB sektor Pariwisata Provinsi Jawa Timur sebesar 66,52 (dalam triliun rupiah) dan memberi kontribusi sebesar 16,66\%, pada tahun 2012 PDRB sektor Pariwisata Provinsi Jawa Timur sebesar 75,61 (dalam triliun rupiah) dan memberi kontribusi sebesar 13,67\%, pada tahun 2013 PDRB sektor Pariwisata Provinsi Jawa Timur sebesar 88,16 (dalam triliun rupiah) dan memberi kontribusi sebesar 16,60\% dan pada tahun 2014 PDRB sektor 
Pariwisata Provinsi Jawa Timur sebesar 101,97 (dalam triliun rupiah) dan memberi kontribusi sebesar 15,67\%.

Berdasarkan kondisi diatas dapat kita ketahui bahwa sektor Pariwisata memberi kontribusi cukup besar yaitu dengan rata 15,65 persen dari tahun 2011-2014, oleh karena itu maka perlu diteliti lebih lanjut tentang seberapa besar pengaruh Pariwisata terhadap produk domestik regional bruto (PDRB) Provinsi Jawa Timur.

Dalam hal ini variabel pariwisata yang diteliti adalah jumlah wisatawan, jumlah hotel dan jumlah restoran.

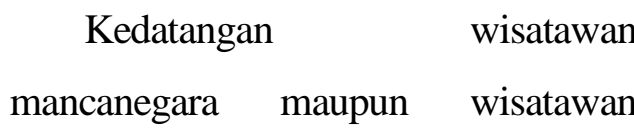
nusantara pada suatu objek wisata akan meningkatkan pendapatan daerah. Konsumsi wisatawan cenderung akan meningkatkan output, barang dan upah di sektor yang menjual barang maupun jasa kepada wisatawan. Konsumsi wisatawan akan menciptakan permintaan baik barang maupun jasa yang pada akhirnya akan menimbulkan kegiatan produksi baik barang maupun jasa yang secara otomatis akan memberi nilai tambah kepada pendapatan regional khususnya produk domestik regional bruto di suatu daerah (Fajriasari, 2013).

Jumlah hotel juga berpengaruh terhadap produk domestik regional bruto kabupaten kota di provinsi jawa timur, hotel adalah sektor yang paling banyak mendapatkan pemasukan dari pengeluaran wisatawan atau konsumsi wisatawan sehingga secara otomatis akan memberi nilai tambah kepada pendapatan regional khususnya produk domestik regional bruto di suatu daerah. Jumlah hotel adalah suatu indikator prodktifitas yang biasa digunakan pada industri pariwisata, semakin tinggi jumlah hotel dan tingkat hunian hotel tersebut permintaan akan pelayanan jasa hotel tersebut akan meningkat dan secara otomatis kegiatan ekonomi dari hotel tersebut akan berdampak pada produk domestik regional bruto. Sektor hotel berpengaruh signifikan dengan arah yang positif terhadap produk domestik regional bruto (Afandi dan Soesatyo, 2012).

Sektor pariwisata tidak lepas dari jasa penyedia makanan dan minuman yaitu restoran, restoran memiliki peran dalam pembentukan PDRB. Terbukti pada penelitian Pradnyana (2009) 
bahwa restoran membawa pengaruh positif terhadap produk domestik regional bruto, artinya bahwa jika sektor restoran meningkat maka produk domestik regional bruto juga meningkat.

Tujuan yang akan dicapai dalam penelitian ini adalah untuk mengetahui perkembangan jumlah wisatawan, jumlah hotel, jumlah restoran dan produk domestik regional bruto Kabupaten dan Kota di Provinsi Jawa Timur, Mengetahui dan menganalisis pengaruh jumlah wisatawan, jumlah hotel dan jumlah restoran terhadap produk domestik regional bruto Provinsi Jawa Timur.

\section{METODE PENELITIAN}

Data yang digunakan dalam penelitian ini adalah sekunder yang didapat dari Badan Pusat Statistik dan Dinas Kebudayaan dan Pariwisata Provinsi Jawa Timur yaitu data produk domestik regional bruto, jumlah wisatawan, jumlah hotel dan jumlah restoran di Kabupaten/Kota Jawa Timur tahun 2011-2014.

1. Regresi Data Panel

Menurut Gujarati (2012:73), analisis regresi berkaitan dengan studi mengenai ketergantungan satu variabel yaitu variabel terikat (dependen) terhadap satu atau lebih variabel lainnya yaitu variabel bebas (independen) dengan tujuan untuk mengestimasi atau memperkirakan nilai rerata atau rata-rata variabel terikat (dependen) dari nilai yang diketahui atau nilai tetap dari variabel bebas (independen). Penelitian ini menggunakan regresi data panel. Data panel adalah data yang diperoleh dengan menggabungkan antara data cross section dan data time series.

Menurut Gujarati (2012:237) terdapat beberapa keuntungan dalam menggunakan data panel antara lain: Dengan menggabungkan data time series dan cross section, dapat memberikan data yang lebih informatif, lebih variatif, mengurangi kolinieritas antar variabel, derajat kebebasan yang lebih banyak dan efisiensi yang lebh besar. Data panel lebih baik untuk mempelajari dinamika perubahan. Data panel dapat berinteraksi lebih baik dan mengukur efek - efek yang tidak dapat diobservasi dalam data cross section murni maupun data time series murni. Data panel memungkinkan peneliti untuk mempelajari model perilaku 
yang lebih rumit. Dengan membuat data tersedia dalam jumlah lebih banyak, data panel dapat meminimumkan bias yang dapat terjadi bila kita mengagregatkan individu ke dalam agregat yang luas. Data panel dapat memperkaya analisis empiris dengan berbagai cara yang mungkin tidak terjadi jika hanya menggunakan data cross section atau data time series. Data panel tidak membutuhkan uji ekonometri. Uji ekonometri dilakukan untuk mengetahui apakah spesifikasi model yang digunakan sudah memenuhi asumsi klasik atau tidak.

Ada tiga teknik yang dapat digunakan dalam perhitungan regresi linier berganda dengan menggunakan data panel teknik OLS (Ordinary Least Square) yaitu Common effect, Fixed effect dan Random effect. Untuk mendapatkan teknik yang paling tepat untuk mengestimasi regresi data panel harus melalui tiga uji yaitu uji Chow, uji LM, uji Hausman.

Sedangkan bentuk umum dari model regresi panel data dapat dirumuskan dengan persamaan sebagai berikut:

$$
Y=\alpha+\beta_{1} X_{1}+\beta_{2} X_{2}+\beta_{3} X_{3}+e
$$

Dimana :

$\mathrm{Y}=$ Produk Domestik Regional Bruto

$\mathrm{X}_{1}=$ Jumlah Wisatawan

$\mathrm{X}_{2}=$ Jumlah Hotel

$\mathrm{X}_{3}=$ Jumlah Restoran

$\alpha=$ Konstanta

$\beta_{1}=$ Koefisien Regresi $\mathrm{X}_{1}$

$\beta_{2}=$ Koefisien Regresi $\mathrm{X}_{2}$

$\beta_{3}=$ Koefisien Regresi $\mathrm{X}_{3}$

$\mathrm{e} \quad=$ Error

\section{PEMBAHASAN}

Perkembangan Produk Domestik Regional Bruto

Berdasarkan data dari Badan Pusat Statistik Provinsi Jawa Timur secara umum besarnya angka Produk Domestik Regional Bruto (PDRB) di provinsi Jawa Timur selalu mengalami peningkatan dari tahun ke tahun (2011-2014) dengan nilai perkembangan rata-rata sebesar 11,29 persen. Pada tahun 2012 total Produk Domestik Regional Bruto (PDRB) sebesar 11,58 persen, pada tahun 2013 naik menjadi 11,21 persen, terus mengalami kenaikan hingga mencapai 11,08 persen pada tahun 2014.

Rata-rata perkembangan Produk Domestik Regional Bruto (PDRB) 
tertinggi pada Tabel 4.2 adalah kabupaten Sidoarjo sebesar 11,98 persen. 13,54 persen pada tahun 2012, 11,21 persen pada tahun 2013 dan 11,18 persen pada tahun 2014 . Rata-rata perkembangan Produk Domestik Regional Bruto (PDRB) terendah adalah kabupaten Bojonegoro sebesar 7 persen. 5,63 persen pada tahun 2012, 10,17 persen pada tahun 2013 dan 5,20 persen pada tahun 2014 .

Berdasarkan data dari Badan Pusat Statistik Provinsi Jawa Timur dapat diketahui bahwa dalam kurun waktu 2011-2014 total Produk Domestik Regional Bruto (PDRB) Kabupaten dan Kota di Provinsi Jawa Timur mengalami peningkatan. Pada tahun 2011 total Produk Domestik Regional Bruto (PDRB) sebesar Rp.1.121.860,7 miliar, pada tahun 2012 naik menjadi Rp.1.251.842,2 miliar, pada tahun 2013 naik menjadi Rp.1.392.261,8 miliar, terus mengalami kenaikan hingga mencapai Rp.1.546.541,1 miliar pada tahun 2014.

Produk Domestik Regional Bruto (PDRB) tertinggi adalah kota Surabaya sebesar Rp.261.772,3 miliar pada tahun 2011, Rp.293.180,8 miliar pada tahun 2012, Rp.327.926,1 miliar pada tahun 2013 dan Rp.365.073,1 miliar pada tahun 2014. Produk Domestik Regional Bruto (PDRB) terendah adalah kota Blitar sebesar Rp.3.183,0 miliar pada tahun 2011, Rp.3.545,8 miliar pada tahun 2012, Rp.3.929,5 pada tahun 2013 dan Rp.4.352,8 miliar pada tahun 2014 .

\section{Perkembangan Jumlah Wisatawan}

Berdasarkan data dari Dinas Kebudayaan dan Pariwisata Provinsi Jawa Timur dapat diketahui bahwa perkembangan jumlah wisatawan Kabupaten dan Kota di Provinsi Jawa Timur mengalami peningkatan. Pada tahun 2012 total perkembangan jumlah wisatawan sebesar 18,99 persen, pada tahun 2013 jumlah wisatawan meningkat menjadi 18,46 persen, terus mengalami kenaikan hingga mencapai 16,28 persen pada tahun 2014.

Kota Surabaya merupakan daerah dengan daya tarik wisatawan paling tinggi di Provinsi Jawa Timur dalam kurun waktu 2011-2014 yaitu 5.353.012 wisatawan pada tahun 2011, 5.028.793 wisatawan pada 
tahun 2012, 5.416.817 wisatawan

pada tahun 2013 dan 5.569.951

wisatawan pada tahun 2014.

Sedangkan daerah dengan daya tarik

wisatawan paling rendah di Provinsi

Jawa Timur dalam kurun waktu

2011-2014 adalah Kota Madiun yaitu

17.447 wisatawan pada tahun 2011,

18.986 wisatawan pada tahun 2012,

22.763 wisatawan pada tahun 2013

dan 44.596 wisatawan pada tahun 2014.

\section{Perkembangan Jumlah Hotel}

Berdasarkan data dari Dinas

Kebudayaan dan Pariwisata Provinsi

Jawa Timur dapat diketahui bahwa

jumlah hotel Kabupaten dan Kota di

Provinsi Jawa Timur mengalami

perkembangan. Pada tahun 2012

total perkembangan jumlah hotel

sebesar 1,63 persen, pada tahun 2013

jumlah hotel meningkat menjadi

11,01 persen, terus mengalami

kenaikan hingga mencapai 3,99

persen pada tahun 2014.

Berdasarkan data dari Dinas

Kebudayaan dan Pariwisata Provinsi

Jawa Timur dapat diketahui bahwa

dalam kurun waktu 2011-2014

jumlah hotel di kabupaten dan kota

di Provinsi Jawa Timur mengalami peningkatan. Pada tahun 2011 jumlah hotel sebanyak 1.286, pada tahun 2012 jumlah hotel meningkat menjadi 1.307, pada tahun 2013 jumlah hotel meningkat menjadi 1.451 dan pada tahun 2014 jumlah hotel meningkat menjadi 1.509.

Jumlah hotel dan akomodasi tertinggi adalah Kabupaten Pasuruan dengan tolal 1.008 hotel dalam kurun waktu 2011-2014. Dimana pada tahun 2011 terdapat 253 hotel, pada tahun 2012 terdapat 253 hotel, pada tahun 2013 terdapat 250 hotel dan pada tahun 2014 terdapat 252 hotel. Dan jumlah hotel dan akomodasi terendah adalah Kabupaten Madiun dengan total 16 hotel. Dimana pada tahun 2011-2014 terdapat 4 hotel saja dalam masing - masing tahun.

\section{Perkembangan Jumlah Restoran}

Berdasarkan data dari Dinas

Kebudayaan dan Pariwisata Provinsi

Jawa Timur Pada tahun 2012 total

perkembangan jumlah restoran

sebesar 6,18 persen, pada tahun 2013

jumlah hotel meningkat menjadi

14,45 persen, terus mengalami

kenaikan hingga mencapai 4,41

persen pada tahun 2014. 
Jumlah restoran Kabupaten dan Kota di Provinsi Jawa timur pada tahun 2011-2014 yang mengalami peningkatan. Pada tahun 2011 jumlah restoran Kabupaten dan Kota di Provinsi Jawa Timur mencapai 1.342, Pada tahun 2012 jumlah restoran Kabupaten dan Kota di Provinsi Jawa Timur meningkat menjadi 1.425, Pada tahun 2013 jumlah restoran Kabupaten dan Kota di Provinsi Jawa Timur meningkat menjadi 1.631, dan pada tahun 2014 jumlah restoran Kabupaten dan Kota di Provinsi Jawa Timur meningkat menjadi 1.703 .

Kabupaten dan Kota yang memiliki jumlah restoran tertingi adalah Kota Surabaya dengan jumlah restoran sebanyak 331 pada tahun 2011, 357 restoran pada tahun 2012, 391 restoran pada tahun 2013 dan 383 restoran pada tahun 2014. Sedangkan daerah dengan jumlah restoran terendah adalah Kabupaten Pacitan dengan jumlah restoran sebanyak 5 pada tahun 2011, 9 restoran pada tahun 2012, 9 restoran pada tahun 2013 dan 12 restoran pada tahun 2014.

Analisis Regresi Linier Berganda.
Berdasarkan hipotesis yang diteliti yaitu diduga bahwa jumlah wisatawan, jumlah hotel dan jumlah restoran berpengaruh signifikan terhadap produk domestik regional bruto Provinsi Jawa Timur, maka untuk membuktikan hipotesis tersebut telah dilakukan pengujian dengan analisis regresi linier berganda menggunakan program eviews 9.

Penelitian ini menggunakan analisis dengan data panel yaitu penggabungan dari metode time-series dan cross-section, dengan menggunakan data panel dapat mengidentifikasi hubungan antara variabel bebas terhadap variabel terikat. Dalam data panel tidak perlu menggunakan uji asumsi klasik, cukup dengan melakukan uji statistik yang meliputi uji f, uji-t dan $\mathrm{R}^{2}$.

Analisis dengan menggunakan data panel mempunyai tiga teknik yang biasa digunakan yaitu : teknik OLS (Common Effect), FEM (Fixed Effect Model) dan REM (Random Effect Model). Adapun untuk menentukan teknik yang paling tepat untuk mengestimasi regresi data panel maka harus melalui uji Chow, uji LM dan uji Hausman. 
Chow test (Uji Chow) yakni pengujian untuk menentukan antara model OLS (Common Effect) tanpa variabel Dummy dan FEM (Fixed Effect Model) mana yang paling tepat untuk digunakan dalam mengestimasi data panel. Dari hasil uji Chow diketahui: Probabilitas statistik $=0.0000$ pada alfa $5 \%(0,05)$, maka dapat disimpulkan bahwa Probabilitas statistik $=$ $0.0000<$ alfa $5 \%(0,05)$ sehingga menolak $\mathrm{H}_{0}$ dan menerima $\mathrm{H}_{1}$, artinya model FEM (Fixed Effect Model) yang paling tepat.

Uji LM digunakan untuk memilih antara model OLS (Common Effect Model) tanpa variabel Dummy dan REM (Random Effect Model) mana yang paling tepat untuk digunakan. Dari hasil uji LM diperoleh nilai Probabilitas Breusch-Pagan $=0.0000$. Maka dapat disimpulkan bahwa Probabilitas Breusch-Pagan $=0.0000<$ alfa $5 \%(0,05)$ sehingga menolak $\mathrm{H}_{0}$ dan menerima $\mathrm{H}_{1}$, artinya model REM (Random Effect Model) yang paling tepat.

\section{Tabel 2. Output Regresi dengan pendekatan Fixed Effect Model}

\begin{tabular}{crrl}
\hline Variabel & Coefficient & t-Statistic & Prob. \\
\hline C & 3.456380 & 36.29086 & 0.0000 \\
X1 & 0.069744 & 4.794563 & 0.0000 \\
X2 & 0.109792 & 2.960742 & 0.0038
\end{tabular}


Analisis Pengaruh Pariwisata Terhadap Produk.............(Yhoga Bagus Adhikrisna)

\begin{tabular}{ccrr}
$\mathrm{X} 3$ & 0.224549 & 4.689228 & 0.0000 \\
\hline Sumber: Data diolah menggunakan
\end{tabular}

Sumber: Data diolah menggunakan eviews 9, 2016. 
Maka diperoleh persamaan umum regresi sebagai berikut:

$$
\begin{aligned}
& \operatorname{LnY}=3.456380+0.069744 \operatorname{LnX} 1+ \\
& 0.109792 \operatorname{LnX} 2+0.224549 \operatorname{LnX} 3 \\
& +\mathrm{e}
\end{aligned}
$$

\section{PEMBAHASAN}

Konstanta $\mathrm{Y}=3.456380 \%$ atau sama dengan 2.860, artinya apabila Jumlah Wisatawan $\left(\mathrm{X}_{1}\right)$, Jumlah Hotel $\left(\mathrm{X}_{2}\right)$, dan Jumlah Restoran $\left(\mathrm{X}_{3}\right)$ sama dengan nol atau dianggap tidak ada, maka besarnya PDRB (Y) adalah 2.860 .

$\beta_{1}\left(X_{1}\right)=0,069744 \%$ atau sama dengan 1,1742, hal ini menunjukan adanya hubungan positif antara Jumlah Wisatawan $\left(\mathrm{X}_{1}\right)$ terhadap PDRB (Y) sebesar 1,1742 yang artinya apabila Jumlah Wisatawan naik sebesar $1 \%$ maka PDRB akan naik sebesar 0,069744\% dengan asumsi variabel lainya tidak mengalami perubahan (tetap).

$$
\beta_{2}\left(X_{2}\right)=0.109792 \% \text { atau sama }
$$

dengan 1,2876, hal ini menunjukan adanya hubungan positif antara Jumlah Hotel $\left(\mathrm{X}_{2}\right)$ terhadap PDRB (Y) sebesar 1,2876 yang artinya apabila Jumlah Hotel naik sebesar 1\% maka PDRB akan naik sebesar $0.109792 \%$ dengan asumsi variabel lainya tidak mengalami perubahan (tetap).

$\beta_{3}\left(X_{3}\right)=0.224549 \%$ atau sama dengan 1,6770, hal ini menunjukan adanya hubungan positif antara Jumlah Restoran $\left(\mathrm{X}_{3}\right)$ terhadap PDRB (Y) sebesar 1,6770, yang artinya apabila Jumlah Restoran naik sebesar 1\% maka PDRB akan naik sebesar $0.224549 \%$ dengan asumsi variabel lainya tidak mengalami perubahan (tetap).

\section{Pengujian Hipotesis}

Pengujian hipotesis dilakukan untuk mengetahui ada atau tidak pengaruh antara variabel bebas terhadap variabel terikat. Pengujian hipotesis meliputi: uji F (simultan), uji t (parsial), dan uji R2 (koefisien determinasi)

\section{Uji T (Parsial)}

Uji $\mathrm{t}$ (parsial) merupakan pengujian untuk mengetahui ada atau tidak pengaruh secara parsial antara masing-masing variabel bebas dengan menggunakan pendekatan fixed effect model yaitu : Jumlah Wisatawan $\left(\mathrm{X}_{1}\right)$, Jumlah Hotel $\left(\mathrm{X}_{2}\right)$, dan Jumlah Restoran $\left(\mathrm{X}_{3}\right)$ terhadap variabel terikat PDRB (Y).

Jumlah Wisatawan $\left(\mathrm{X}_{1}\right)$ memiliki nilai $t_{\text {statistik }}$ sebesar 4.794563 dengan 
nilai probabilitas sebesar 0.0000 dan nilai $t_{\text {tabel }}$ sebesar 1.97612, maka dapat disimpulkan bahwa nilai $\mathrm{t}_{\text {statistik }}$ $4.794563>\mathrm{t}_{\text {tabel }} 1.97612$, yang artinya menerima $\mathrm{H}_{1}$ dan menolak $\mathrm{H}_{0}$. dengan demikian dapat disimpulkan bahwa variabel Jumlah Wisatawan $\left(\mathrm{X}_{1}\right)$ berpengaruh secara signifikan dengan arah yang positif terhadap PDRB (Y).

Jumlah Hotel $\left(\mathrm{X}_{2}\right)$ memiliki nilai $\mathrm{t}_{\text {statistik }}$ sebesar 2.960742 dengan nilai probabilitas sebesar 0.0038 dan nilai $\mathrm{t}_{\text {tabel }}$ sebesar 1.97612, maka dapat disimpulkan bahwa nilai $\mathrm{t}_{\text {statistik }}$ $2.960742>1.97612$, yang artinya menerima $\mathrm{H}_{1}$ dan menolak $\mathrm{H}_{0}$. Dengan demikian dapat disimpulakan bahwa variabel Jumlah Hotel $\left(\mathrm{X}_{2}\right)$ berpengaruh secara signifikan dengan arah yang positif terhadap PDRB (Y).

Jumlah Restoran $\left(\mathrm{X}_{3}\right)$ memiliki nilai $t_{\text {statistik }}$ sebesar 4.689228 dengan nilai probabilitas sebesar 0.0000 dan nilai $t_{\text {tabel }}$ sebesar 1.97612 , maka dapat disimpulkan bahwa nilai $t_{\text {statistik }}$ $4.689228>\mathrm{t}_{\text {tabel }} 1.97612$, yang artinya menerima $\mathrm{H}_{1}$ dan menolak $\mathrm{H}_{0}$. Dengan demikian dapat disimpulkan bahwa variabel Jumlah Restoran $\left(\mathrm{X}_{3}\right)$ berpengaruh signifikan dengan arah positif terhadap PDRB (Y).

\section{Uji F (F-test)}

\section{Tabel 3. Uji F (F-test)}

\begin{tabular}{lllr} 
R-squared & 0.991323 & Mean dependent var & 4.306285 \\
Adjusted R-squared & 0.988197 & S.D. dependent var & 0.423013 \\
S.E. of regression & 0.045958 & Akaike info criterion & -3.097067 \\
Sum squared resid & 0.234444 & Schwarz criterion & -2.281415 \\
Log likelihood & 276.3771 & Hannan-Quinn criter. & -2.765721 \\
F-statistic & 317.0460 & Durbin-Watson stat & 1.335567 \\
Prob(F-statistic) & 0.000000 & & \\
\hline
\end{tabular}

Sumber: Data diolah menggunakan eviews 9, 2016

Uji F (simultan) merupakan Restoran $\left(\mathrm{X}_{3}\right)$ terhadap variabel pengujian untuk mengetahui ada atau tidaknya pengaruh secara simultan terikat PDRB (Y).

Berdasarkan hasil pengujian $\mathrm{F}$ (serentak) antara variabel bebas statistik diatas diperoleh nilai $\mathrm{F}_{\text {statistik }}$ yaitu: Jumlah Wisatawan $\left(\mathrm{X}_{1}\right)$, $=317.0460$ pada alfa $5 \%(0,05)$, Df1 Jumlah Hotel $\left(\mathrm{X}_{2}\right)$, dan Jumlah $=\mathrm{k}-1=4-1=3$, Df $2=\mathrm{n}-\mathrm{k}=152-4$ 
$=148$ diperoleh nilai $\mathrm{F}_{\text {tabel }}=2.67$, maka dapat disimpulkan bahwa $\mathrm{F}_{\text {statistik }} 317.0460>\mathrm{F}_{\text {tabel }} 2.67$ sehingga menolak $\mathrm{H}_{0}$ dan menerima $\mathrm{H}_{1}$ yang artinya variabel bebas yaitu : Jumlah Wisatawan $\left(\mathrm{X}_{1}\right)$, Jumlah Hotel $\left(\mathrm{X}_{2}\right)$, dan Jumlah Restoran $\left(\mathrm{X}_{3}\right)$ berpengaruh secara serentak (bersama-sama) terhadap variabel terikat PDRB (Y).

\section{Uji Koefesien Determinasi $\mathbf{R}^{2}$}

Uji koefisien determinasi $\mathrm{R}^{2}$ dilakukan untuk mengetahui sseberapa jauh kemampuan variabel bebas yaitu : jumlah wisatawan (X1), jumlah hotel (X2) dan jumlah restoran (X3) mampu menjelaskan variabel terikat produk domestik regional bruto $(\mathrm{Y})$.

Sesuai pengamatan dan perhitungan maka dapat diperoleh nilai adjusted R-Square $\left(R^{2}\right)$ sebesar 0.988197 atau $98 \%$ yang berarti bahwa variabel bebas yaitu Jumlah Wisatawan $\left(\mathrm{X}_{1}\right)$, Jumlah Hotel $\left(\mathrm{X}_{2}\right)$, dan Jumlah Restoran $\left(\mathrm{X}_{3}\right)$ mampu menjelaskan variabel terikat PDRB (Y) sebesar 98\% sementara sisanya $2 \%$ dijelaskan oleh variabel lain diluar model.

\section{KESIMPULAN}

Berdasarkan hasil penelitian serta perhitungan yang telah dilakukan yaitu dengan judul analisis pengaruh pariwisata terhadap produk domestik regional bruto Kabupaten/Kota di Provinsi Jawa Timur. Dengan menggunakan analisis Regresi Linier Berganda data panel di Provinsi Jawa Timur tahun 2010-2014 sehingga diambil kesimpulan sebagai berikut:

1. Pada kurun waktu 2011-2014 Produk Domestik Regional Bruto, Jumlah Wisatawan, Jumlah Hotel dan Jumlah Restoran di Kabupaten/Kota Provinsi Jawa Timur selalu meningkat setiap tahunnya. Pada tahun 2011 jumlah Produk Domestik Regional Bruto sebesar Rp.1.121.860,7 miliar, jumlah Wisatawan sebesar 5.353.012, jumlah Hotel sebesar 1.286, jumlah Restoran sebesar 1.342. Pada tahun 2012 jumlah Produk Domestik Regional Bruto berkembang sebesar 11,58 persen menjadi Rp.1.251.842,2 miliar, jumlah Wisatawan berkembang sebesar 18,99 persen menjadi 5.028.793 jiwa, jumlah Hotel berkembang sebesar 1,63 persen menjadi 1.307 unit, jumlah Restoran berkembang sebesar 6,18 persen 
menjadi 1.425 unit. Pada tahun 2013 jumlah Produk Domestik Regional Bruto berkembang sebesar 11,21 persen menjadi Rp.1.392.261,8 miliar, jumlah Wisatawan berkembang sebesar 18,46 persen menjadi 5.416 .817 jiwa, jumlah Hotel berkembang sebesar 11,01 persen menjadi 1.451 unit, jumlah Restoran berkembang sebesar 14,15 persen menjadi 1.631 unit. Pada tahun 2014 jumlah Produk Domestik Regional Bruto berkembang sebesar 11,08 persen menjadi Rp. 1.546.541,1 miliar, jumlah Wisatawan berkembang sebesar 16,28 persen menjadi 5.569.951 jiwa, jumlah Hotel berkembang sebesar 3,99 persen menjadi 1.509 unit, jumlah Restoran berkembang sebesar 4,41 persen menjadi 1.703 unit.

2. Berdasarkan hasil estimasi model yang terpilih adalah fixed effect. Hasil pengujian $\mathrm{F}$ statistik diatas diperoleh nilai $\mathrm{F}_{\text {statistik }}=317.0460>\mathrm{F}_{\text {tabel }} 2,67$ sehingga menolak $\mathrm{H}_{0}$ dan menerima $\mathrm{H}_{1}$ yang artinya variabel bebas yaitu : Jumlah Wisatawan $\left(\mathrm{X}_{1}\right)$, Jumlah Hotel $\left(\mathrm{X}_{2}\right)$, dan Jumlah Restoran $\left(\mathrm{X}_{3}\right)$ berpengaruh secara serentak (bersamasama) terhadap variabel terikat PDRB (Y). Hasil pengujian t statistik jumlah
Wisatawan $\left(\mathrm{X}_{1}\right)$ diperoleh nilai $\mathrm{t}_{\text {statistik }}$ $4.794563>\mathrm{t}_{\text {tabel }} 1.97612$ dengan nilai probabilitas sebesar 0.0000 dapat disimpulkan bahwa variabel Jumlah Wisatawan $\left(\mathrm{X}_{1}\right)$ berpengaruh secara signifikan dengan arah yang positif terhadap PDRB (Y). Jumlah Hotel $\left(\mathrm{X}_{2}\right)$ diperoleh nilai $t_{\text {statistik }} 2.960742>t_{\text {tabel }}$ 1.97612 dengan nilai probabilitas sebesar 0.0038 dapat disimpulakan bahwa variabel Jumlah Hotel $\left(\mathrm{X}_{2}\right)$ berpengaruh secara signifikan dengan arah yang positif terhadap PDRB (Y). Jumlah Restoran $\left(\mathrm{X}_{3}\right)$ diperoleh nilai $\mathrm{t}_{\text {statistik }}$ sebesar $4.689228>\mathrm{t}_{\text {tabel }} 1.97612$ dengan nilai probabilitas sebesar 0.0000 dapat disimpulkan bahwa variabel Jumlah Restoran $\left(\mathrm{X}_{3}\right)$ berpengaruh signifikan dengan arah positif terhadap PDRB (Y). Uji $\mathrm{R}^{2}$ diperoleh nilai adjusted $\mathrm{R}$-Square $\left(\mathrm{R}^{2}\right)$ sebesar 0.988197 atau $98 \%$ artinya variabel bebas yaitu Jumlah Wisatawan $\left(\mathrm{X}_{1}\right)$, Jumlah Hotel $\left(\mathrm{X}_{2}\right)$, dan Jumlah Restoran $\left(\mathrm{X}_{3}\right)$ mampu menjelaskan variabel terikat PDRB (Y) sebesar 98\% sementara sisanya $2 \%$ dijelaskan oleh variabel lain diluar model.

\section{DAFTAR PUSTAKA}

Afandi, Akhmad Ghofir dan Soesatyo, Yoyok. 2012. 
Pengaruh Industri Pengolahan, Perdagangan, Hotel, Dan Restoran, Dan Pertanian Terhadap pdrb Kabupaten Mojokerto. Univestitas Negeri Surabaya

Badan Pusat Statistik Provinsi Jawa Timur. 2015. Produk Domestik Regionl Bruto Menurut Lapangan Usaha 2010 - 2014. Jawa Timur, CV Bima Media Mandiri.

Dinas Kebudayaan dan Pariwisata Provinsi Jawa Timur. 2015. Pariwisata Dalam Angka.

Fajriasari, Ana. 2013. Pengaruh Jumlah Wisatawan, Lama Tinggal, Dan Pengeluarannya Terhadap Produk Domestik Regional Bruto Sektor Pariwisata Di Jawa Tengah. Universitas Pendidikan Indonesia.
Gujarati, D.N. dan D.C. Porter, 2012. Dasar-Dasar Ekonometrika, Edisi 5 Buku 2. Salemba Empat, Jakarta.

Heriawan, Rusman. 2004. Peranan dan Dampak Pariwisata pada Perekonomian Indonesia, Suatu Pendekatan Model I-O dan SAM. Disertasi. Sekolah Pascasarjana Institut Pertanian Bogor.

Nizar, Muhammad Afdi. 2011. Pengaruh Pariwisata Terhadap Pertumbuhan Ekonomi di Indonesia. Jurnal.

Pradnyana, I Gusti Gede Oka. 2009. Pengaruh Sektor Pertanian dan Sektor Perdagangan, Hotel dan Restoran Terhadap Produk Domestik Regional Bruto Kota Denpasar.

Undang-Undang nomor 10 tahun 2009 Tentang Kepariwisataan 
Analisis Pengaruh Pariwisata Terhadap Produk............(Yhoga Bagus Adhikrisna) 